УДК 597.2/5:574.5(477.75)

\title{
СОВРЕМЕННОЕ СОСТОЯНИЕ ИХТИОКОМПЛЕКСА КАРАДАГСКОГО ПРИРОДНОГО ЗАПОВЕДНИКА
}

Мальцев В.И. ${ }^{1}$, Шаганов В.В. ${ }^{2}$, Василец В.Е. ${ }^{1}$

${ }^{l}$ ФГБУН «Карадагская научная станция им. Т.И.Вяземского - природный заповедник РАН», 2.Феодосия, пгт. Курортное, Российская Федераиия, е-mail: maltsev1356@gmail.com

${ }^{2}$ ФГБОУ ВО «Керченский государственный морской технологический университет» 2. Керчь, Российская Федерачия, e-mail: vshaganov@yandex.ru

В период 2012-2017 гг. методами визуальных учётов, видеоучётов в акватории Карадагского природного заповедника, а также на основании данных промстатистики и информации от рыбаков-любителей, осуществляющих лов на примыкающих к заповеднику акваториях, выявлено 49 видов рыб. Анализ литературных данных об изучении ихтиокомплекса акватории заповедника в продолжение 25 лет показал, что ещё 2 вида также могут быть отнесены к ихтиокомплексу акватории заповедника. Таким образом, общее количество видов ихтиокомплекса акватории Карадагского природного заповедника насчитывает 51. Прочие 60 видов, ранее включавшиеся в списки видов акватории заповедника, либо не встречаются более 25 лет, либо объединены с другими видами в результате пересмотра их систематики. Из видов, присутствие которых в акватории заповедника подтверждено, в Красную книгу Республики Крым включено 2 вида, в Красный список Международного союза охраны природы (МСОП) 3 , в Красную книгу Чёрного моря (Black Sea Red Data Book) - 18; в охранные списки Бернской конвенции включены 3 вида.

Ключевые слова: Карадагский природный заповедник, акватория заповедника, виды рыб, визуальный учёт, видеоучет, промысловая статистика, данные любительского рыболовства.

\section{Введение}

Создание заповедных объектов призвано сохранять наиболее ценные природнотерриториальные комплексы, включая биотическую составляющую и типичные местообитания. Особое значение для сохранения природного комплекса имеют заповедные объекты, включающие как сухопутную часть, так и акваторию, таковым является и Карадагский природный заповедник, созданный в 1979 г.

Прибрежная акватория заповедника (809 га) характеризуется наличием почти сплошного каменисто-скалистого пояса, сложенного булыжно-галечными наносами (размер камней 10-300 см), образованными породами вулканического происхождения. Имеются также большие глыбы и скалы, вертикально спускающиеся в море. Песчаные донные отложения у побережья существуют только в виде небольших вкраплений среди нагромождений камней, а на отдалении 100-200 м становятся преобладающим типом субстрата.

В результате создания заповедных объектов возникла необходимость ведения мониторинга биоразнообразия на подконтрольных территориях и акваториях, в том числе и их рыбного населения. Эта информация становится неотъемлемой частью Летописи природы.

За 100-летнюю историю существования научного и природоохранного учреждения на Карадаге рыбное население исследовалось многократно. Существует значительное количество публикаций, содержащих списки видов рыб, встреченных в непосредственной близости от Карадага (Виноградов, 1930, 1947, 1949; Прокудина, 1952; Смирнов, 1959; Салехова, Костенко и др., 1987; Салехова, Костенко, 1989; Костенко, Шаганов, 2004), включая современную заповедную акваторию. Упомянутые списки формировались как на основании проводимых исследований, так и с 
использованием предшествующих перечней, что расширило официальный список видов, обитающих в акватории, до 114. В связи с этим целю данного исследования является анализ современного состояния ихтиокомплекса заповедной акватории Карадагского природного заповедника.

\section{Материалы и методы}

Заповедный статус исследуемой акватории и обусловленные им ограничения на ловы требуют бесконтактных способов учёта, поэтому в течение 6 лет мы разрабатывали и совершенствовали альтернативные, нетравматичные методы, а именно визуального учёта и видеоучёта (Мальцев, Иванчикова, 2015; Мальцев, Алексеев, 2016).

Визуальный учёт рыб прибрежного ихтиокомплекса осуществлялся способом «на задержке дыхания» (Гетман, 2007). Учёт проводился как в пределах трансект длиной 25-50 м и шириной 10 м, так и при «маршрутных» наблюдениях на отдельных участках. Всего в 2012-2016 гг. проведено около 150 таких учётов и наблюдений в пределах заповедной акватории (бухтах Биостанции, Львиной, Разбойничьей, Сердоликовой, Лягушачьей, у скалы «Золотые Ворота», на участке у Камня Кузьмича).

Видеоучет осуществлялся с помощью подводного автономного видеорегистрирующего устройства (ПАВУ), основой которого является автомобильный видеорегистратор с разрешением Full HD (1080p) и углом обзора 130, помещенный в герметичный бокс (Мальцев, Алексеев, 2016). ПАВУ выставлялось на мелководье для экспозиции от 50 до 90 минут. После экспозиции карта памяти видеорегистратора извлекалась и просматривалась с помощью ПК с соответствующим программным обеспечением. Все попавшие в поле зрения рыбы учитывались. Всего в 2015-2016 гг. проведено 18 видеоучётов в бухтах Биостанции, Львиной, Сердоликовой, а также у скалы «Золотые Ворота».

Кроме того, в работе использована информация о видовом составе уловов за 20152016 гг. ИП «Дроздов», осуществляющего промысел в западной части Коктебельского залива в непосредственной близости от заповедной акватории, а также информация о видовом составе любительских ловов в акватории, примыкающей к заповедной.

Порядок перечисления семейств, латинские и русские названия видов рыб даны по Е.Д. Васильевой (2007).

\section{Результаты и обсуждение}

В результате наших исследований 2012-2017 гг. выявлено 49 видов рыб (табл. 1). Прочие 62 вида были встречены акватории, прилегающей к Карадагу, с 1927 по 2002 гг.

Учитывая логику формирования категорий природоохранного статуса (Красная книга Республики Крым, 2015), представляется правильным не исключать из списков видов, обитающих на заповедной акватории, виды, встреченные здесь в продолжение последних 25 лет, т.е. с 1993 по 2017 гг. Виды, не встреченные в период наших исследований 2012-2017 гг., но нахождение которых в акватории заповедника укладывается во временной интервал 1993-2017 гг., представлены в таблице 2. Таким образом, есть основание считать, что акватория заповедника так или иначе поддерживает существование популяций 51 вида, которые поименованы в таблицах 1 и 2.

Прочие 60 видов (табл. 3), ранее включавшиеся в списки видов акватории заповедника, либо не встречаются более 25 лет, либо объединены с другими видами в результате пересмотра их систематики. Включать в список видов заповедной акватории представляется нецелесообразным до тех пор, пока их присутствие не будет вновь установлено. 
Таблица 1.

Видовой состав прибережного ихтиокомплекса акватории Карадагского природного заповедника, представленный на основе анализа информации из разных источников (2012-2017 гг.): ВУ - по данным визуальных учётов, ВР - по данным видеорегистрации, ЛЛ- по данным любительских ловов, ПУ - по данным промысловых уловов; ККр. - красная книга Республики Крым, МСОП - Красный список Международного союза охраны природы, Берн. - Охранные списки Бернской конвенции, КЧ - Красная книга Чёрного моря; Осед. - оседлые виды, Коч. - видыкочевники, Миг. - мигрирующие виды)

\begin{tabular}{|c|c|c|c|c|c|}
\hline № & Виды & $\begin{array}{c}\text { Способ } \\
\text { обнаружения }\end{array}$ & $\begin{array}{c}\text { Природоохранный } \\
\text { статус }\end{array}$ & Информация & $\begin{array}{c}\text { Экологические } \\
\text { особенности }\end{array}$ \\
\hline \multicolumn{6}{|c|}{ Сем. Squalidae - Катрановые } \\
\hline 1. & $\begin{array}{l}\text { Squalus acanthias L., } \\
1758 \text { - катран }\end{array}$ & ПУ & $\begin{array}{l}\text { MCOП (Endan- } \\
\text { gered) }\end{array}$ & $\begin{array}{l}\text { Придонно-пелагический вид, } \\
\text { держится, как правило, вдали } \\
\text { от берегов. В последние годы } \\
\text { иногда попадается в ставные } \\
\text { орудия лова и на крючковые } \\
\text { снасти рыболовов-любителей } \\
\text { на сопредельных к } \\
\text { заповеднику акваториях. }\end{array}$ & Миг. \\
\hline \multicolumn{6}{|c|}{ Cем. Rajidae - Скатовые } \\
\hline 2. & $\begin{array}{l}\text { Raja clavata L., } \\
1758 \text { - морская } \\
\text { лисица }\end{array}$ & ЛЛ & & $\begin{array}{l}\text { Донный вид. Обитатель } \\
\text { преимущественно песчаных } \\
\text { грунтов, изредка попадается } \\
\text { на крючки рыболовов- } \\
\text { любителей на прилегающей } \\
\text { к заповеднику акватории. }\end{array}$ & Коч. \\
\hline \multicolumn{6}{|c|}{ Сем. Dasyatidae - Хвостоколовые } \\
\hline 3. & $\begin{array}{l}\text { Dasyatis pastinaca } \\
\text { (L., 1758) - морской } \\
\text { кот }\end{array}$ & ВУ, ПУ & $\begin{array}{l}\text { MCOП-(Vulner- } \\
\text { able) }\end{array}$ & $\begin{array}{l}\text { Донный вид, держится } \\
\text { обычно на мягких, как } \\
\text { правило, песчаных грунтах, } \\
\text { на разных глубинах, вплоть } \\
\text { до } 100 \text { м, может подходить к } \\
\text { берегу. В условиях наших } \\
\text { наблюдений встречался } 1 \text { раз } \\
\text { вблизи Кузьмичева Камня. } \\
\text { Является объектом промысла, } \\
\text { изредка попадается на } \\
\text { крючки рыболовов- } \\
\text { любителей на прилегающей к } \\
\text { заповеднику акватории. }\end{array}$ & Коч. \\
\hline \multicolumn{6}{|c|}{ Сем. Engraulidae - Анчоусовые } \\
\hline 4. & $\begin{array}{l}\text { Engraulis } \\
\text { encrasicolus (L., } \\
\text { 1758)- хамса }\end{array}$ & ПУ & & $\begin{array}{l}\text { Стайный пелагический вид, } \\
\text { объект промысла на } \\
\text { прилегающей к заповеднику } \\
\text { акватории. }\end{array}$ & Миг. \\
\hline \multicolumn{6}{|c|}{ Сем. Clupeidae - Сельдевые } \\
\hline 5. & $\begin{array}{l}\text { Alosa immaculata } \\
\text { Bennett, } 1835- \\
\text { сельдь } \\
\text { черноморская }\end{array}$ & ЛЛ, ПУ & $\begin{array}{l}\text { МСОП (Vulner- } \\
\text { able), Берн }\end{array}$ & $\begin{array}{l}\text { Стайный пелагический вид. } \\
\text { Объект промысла и } \\
\text { любительского рыболовства } \\
\text { на прилегающей к } \\
\text { заповеднику акватории. }\end{array}$ & Миг. \\
\hline
\end{tabular}




\begin{tabular}{|c|c|c|c|c|c|}
\hline № & Виды & $\begin{array}{c}\text { Способ } \\
\text { обнаружения }\end{array}$ & $\begin{array}{c}\text { Природоохранный } \\
\text { статус }\end{array}$ & Информация & $\begin{array}{c}\text { Экологические } \\
\text { особенности }\end{array}$ \\
\hline \multicolumn{6}{|c|}{ Сем. Ophidiidae - Ошибневые } \\
\hline 6. & $\begin{array}{l}\text { Ophidion rochei } \\
\text { Muller, } 1845 \text { - } \\
\text { ошибень }\end{array}$ & ЛЛ & & $\begin{array}{l}\text { Донный вид, обитатель } \\
\text { песчаных грунтов, в } \\
\text { пределах заповедной } \\
\text { акватории и на прилегающих } \\
\text { акваториях (случайный } \\
\text { объект любительского лова) } \\
\text { немногочислен. }\end{array}$ & Осед. \\
\hline \multicolumn{6}{|c|}{ Сем. Phycidae - Нитепёрые налимы } \\
\hline 7. & $\begin{array}{l}\text { Gaidropsarus } \\
\text { mediterraneus (L., } \\
\text { 1758) - налим } \\
\text { морской }\end{array}$ & ВУ, ЛЛ, ПУ & & $\begin{array}{l}\text { Донный прибрежный вид, } \\
\text { обитатель каменистых } \\
\text { участков, заросших } \\
\text { макроводорослями. } \\
\text { Визуальные наблюдения в } \\
\text { заповедной акватории } \\
\text { показали присутствие этого } \\
\text { вида ранней весной. В } \\
\text { промысловый ставной невод } \\
\text { на прилегающей к } \\
\text { заповеднику акватории } \\
\text { попадается в качестве } \\
\text { прилова, как и на крючки } \\
\text { рыболовов-любителей. }\end{array}$ & Осед. \\
\hline \multicolumn{6}{|c|}{ Сем. Gadidae - Тресковые } \\
\hline 8. & $\begin{array}{l}\text { Merlangius } \\
\text { merlangus }(\mathrm{L} ., 1758) \\
\text { - черноморский } \\
\text { мерланг }\end{array}$ & ЛЛ & & $\begin{array}{l}\text { Придонно-пелагический вид. } \\
\text { Попадает в промысловый } \\
\text { ставной невод на } \\
\text { прилегающей к заповеднику } \\
\text { акватории, а также на крючки } \\
\text { рыболовов-любителей. }\end{array}$ & Миг. \\
\hline \multicolumn{6}{|c|}{ Сем. Mugilidae - Кефалевые } \\
\hline 9. & $\begin{array}{l}\text { Mugil cephalus L., } \\
1758 \text { - лобан }\end{array}$ & ПУ & & $\begin{array}{l}\text { Пелагический вид, объект } \\
\text { промысла и любительского } \\
\text { лова на прилегающей к } \\
\text { заповеднику акватории. }\end{array}$ & Миг. \\
\hline 10. & $\begin{array}{l}\text { Liza aurata (Risso, } \\
\text { 1810) - сингиль }\end{array}$ & $\begin{array}{l}\text { ВУ, ВР, ЛЛ, } \\
\text { ПУ }\end{array}$ & & $\begin{array}{l}\text { Пелагический вид, один из } \\
\text { основных объектов } \\
\text { промысла и любительского } \\
\text { лова на акватории, } \\
\text { непосредственно } \\
\text { примыкающей к } \\
\text { заповеднику. Во время } \\
\text { наших визуальных учётов и } \\
\text { видеонаблюдений на } \\
\text { прибрежных мелководьях - } \\
\text { обычный вид, иногда даже } \\
\text { массовый. }\end{array}$ & Миг. \\
\hline 11. & $\begin{array}{l}\text { Liza haematocheilus } \\
\text { (Temminck et } \\
\text { Schlegel, 1845) - } \\
\text { пиленгас }\end{array}$ & ЛЛ, ПУ & & $\begin{array}{l}\text { Пелагический вид, объект } \\
\text { промысла и любительского } \\
\text { лова на прилегающей к } \\
\text { заповеднику акватории. } \\
\text { Вселенец. }\end{array}$ & Миг. \\
\hline
\end{tabular}




\begin{tabular}{|c|c|c|c|c|c|}
\hline № & Виды & $\begin{array}{c}\text { Способ } \\
\text { обнаружения }\end{array}$ & $\begin{array}{c}\text { Природоохранный } \\
\text { статус }\end{array}$ & Информация & $\begin{array}{c}\text { Экологические } \\
\text { особенности }\end{array}$ \\
\hline \multicolumn{6}{|c|}{ Сем. Atherinidae - Атериновые } \\
\hline 12. & $\begin{array}{l}\text { Atherina boyeri } \\
\text { Risso, } 1810- \\
\text { атерина } \\
\text { черноморская }\end{array}$ & $\begin{array}{l}\text { ВУ, ВР, ЛЛ, } \\
\text { ПУ }\end{array}$ & & $\begin{array}{l}\text { Пелагический вид, однако в } \\
\text { условиях наших наблюдений } \\
\text { немногочислен, встречались } \\
\text { как взрослые особи, так и } \\
\text { сеголетняя молодь. Обычный }\end{array}$ & Миг. \\
\hline \multicolumn{6}{|c|}{ Сем. Belonidae - Саргановые } \\
\hline 13. & $\begin{array}{l}\text { Belone belone (L., } \\
\text { 1761) - сарган }\end{array}$ & ЛЛ, ПУ & КЧ & $\begin{array}{l}\text { Пелагический вид, является } \\
\text { достаточно обычным } \\
\text { объектом промысла и } \\
\text { любительского лова на } \\
\text { прилегающих к заповеднику } \\
\text { акваториях. В промысловых } \\
\text { количествах обычно } \\
\text { появляется в марте-апреле и } \\
\text { сентябре-ноябре; зимой } \\
\text { откочёвывает на большие } \\
\text { глубины (Смирнов, 1959). В } \\
\text { настоящее время отмечается } \\
\text { измельчание вылавливаемых } \\
\text { особей (20-30 см). }\end{array}$ & Миг. \\
\hline \multicolumn{6}{|c|}{ Сем. Gasterosteidae - Колюшковые } \\
\hline 14. & $\begin{array}{l}\text { Gasterosteus } \\
\text { aculeatus L., } 1758 \text { - } \\
\text { трёхиглая колюшка }\end{array}$ & ЛЛ & & $\begin{array}{l}\text { Прибрежный вид, в } \\
\text { акватории заповедника } \\
\text { редкий, встречается не } \\
\text { каждый год. }\end{array}$ & Коч. \\
\hline \multicolumn{6}{|c|}{ Сем. Syngnathidae - Игловые } \\
\hline 15. & $\begin{array}{l}\text { Hipросатриs } \\
\text { hippoсатриs }(\mathrm{L} ., \\
1758)- \text { конёк } \\
\text { морской }\end{array}$ & BY & ККр, Берн, КЧ & $\begin{array}{l}\text { Фитофильный вид, обитает в } \\
\text { зарослях макрофитов, } \\
\text { встречается и в толще воды, } \\
\text { обычно с апреля по июль } \\
\text { (Смирнов, 1959). Во время } \\
\text { наших исследований встречен } \\
\text { один раз, случайно } \\
\text { прицепившимся к верёвке } \\
\text { дночерпателя (апрель } 2016 \text { г.). }\end{array}$ & Коч. \\
\hline 16. & $\begin{array}{l}\text { Syngnathus typhle L., } \\
1758 \text { - рыба-игла } \\
\text { длиннорылая }\end{array}$ & BY & ККр, КЧ & $\begin{array}{l}\text { Прибрежный фитофильный } \\
\text { вид, обитает в зарослях } \\
\text { макрофитов, встречается и в } \\
\text { толще воды. В акватории } \\
\text { заповедника достаточно редок. }\end{array}$ & Коч. \\
\hline \multicolumn{6}{|c|}{ Сем. Scorpaenidae - Скорпеновые } \\
\hline 17. & $\begin{array}{l}\text { Scorpaena porcus L., } \\
1758 \text { - скорпена }\end{array}$ & ВУ, ЛЛ, ПУ & КЧ & $\begin{array}{l}\text { Донный вид, населяющий } \\
\text { каменистые, заросшие } \\
\text { макроводорослями } \\
\text { субстраты. Является } \\
\text { объектом промысла и } \\
\text { любительского лова на } \\
\text { прилегающей к заповеднику } \\
\text { акватории. Во время } \\
\text { визуальных учётов в марте }\end{array}$ & Осед. \\
\hline
\end{tabular}




\begin{tabular}{|c|c|c|c|c|c|}
\hline № & Виды & $\begin{array}{c}\text { Способ } \\
\text { обнаружения }\end{array}$ & $\begin{array}{c}\text { Природоохранный } \\
\text { статус }\end{array}$ & Информация & $\begin{array}{c}\text { Экологические } \\
\text { особенности }\end{array}$ \\
\hline & & & & $\begin{array}{l}2016 \text { г. отмечен как массовый } \\
\text { на участке «Кузьмичев } \\
\text { Камень», единичные особи } \\
\text { там отмечались также в } \\
\text { летний период того же } 2016 \text { г. }\end{array}$ & \\
\hline \multicolumn{6}{|c|}{ Сем. Triglidae - Тригловые } \\
\hline 18. & $\begin{array}{l}\text { Chelidonichthys } \\
\text { lucernus (L., 1758) - } \\
\text { тригла }\end{array}$ & ЛЛ & ККр, КЧ & $\begin{array}{l}\text { Придонный вид, тяготеет к } \\
\text { песчаным грунтам. } \\
\text { Встречается редко, } \\
\text { попадается в качестве } \\
\text { прилова в уловах рыбаков- } \\
\text { любителей на сопредельной с } \\
\text { заповедником акватории. }\end{array}$ & Коч. \\
\hline \multicolumn{6}{|c|}{ Сем. Serranidae - Каменные окуни } \\
\hline 19. & $\begin{array}{l}\text { Serranus cabrilla } \\
\text { (L., 1758) - } \\
\text { каменный окунь } \\
\text { (ханос) }\end{array}$ & ЛЛ & & $\begin{array}{l}\text { Придонно-фитофильный вид, } \\
\text { предпочитающий } \\
\text { каменистые, заросшие } \\
\text { макроводорослями } \\
\text { субстраты. Редко становится } \\
\text { добычей рыбаков-любителей } \\
\text { на прилегающей к } \\
\text { заповеднику акватории. }\end{array}$ & Коч. \\
\hline \multicolumn{6}{|c|}{ Сем. Pomatomidae - Луфаревые } \\
\hline 20. & $\begin{array}{l}\text { Pomatomus saltatrix } \\
\text { (L., 1766) - луфарь }\end{array}$ & ВР, ЛЛ & & $\begin{array}{l}\text { Пелагический стайный вид. } \\
\text { Массовый подход молоди } \\
\text { луфаря к берегам у } \\
\text { заповедника имеет место, хоть } \\
\text { и не ежегодно, в июле-августе } \\
\text { и продолжается до сентября- } \\
\text { октября, пока температура } \\
\text { воды превышает 20оС (Овен, } \\
\text { 1957, Трифонов, 1960). Так, в } \\
\text { 2016 г. в августе-сентябре } \\
\text { молодые особи длиной 15-25 } \\
\text { см были главным объектом } \\
\text { любительского лова на } \\
\text { границах заповедной } \\
\text { акватории. }\end{array}$ & Миг. \\
\hline \multicolumn{6}{|c|}{ Сем. Carangidae - Ставридовые } \\
\hline 21. & $\begin{array}{l}\text { Trachurus } \\
\text { mediterraneus } \\
\text { (Steindachner, 1868) } \\
\text { - ставрида } \\
\text { черноморская }\end{array}$ & ВУ, ЛЛ, ПУ & & $\begin{array}{l}\text { Пелагический вид, один из } \\
\text { основных объектов } \\
\text { промысла и любительского } \\
\text { лова на акватории, } \\
\text { непосредственно } \\
\text { примыкающей к } \\
\text { заповеднику. По данным } \\
\text { А.Н. Смирнова (1959), к } \\
\text { берегам у Карадага ставрида } \\
\text { подходит с мая по ноябрь. } \\
\text { Тем не менее во время наших } \\
\text { визуальных учётов и } \\
\text { видеонаблюдений на }\end{array}$ & Миг. \\
\hline
\end{tabular}




\begin{tabular}{|c|c|c|c|c|c|}
\hline № & Виды & $\begin{array}{c}\text { Способ } \\
\text { обнаружения }\end{array}$ & $\begin{array}{c}\text { Природоохранный } \\
\text { статус }\end{array}$ & Информация & $\begin{array}{l}\text { Экологические } \\
\text { особенности }\end{array}$ \\
\hline & & & & $\begin{array}{l}\text { прибрежных мелководьях } \\
\text { встречался редко. }\end{array}$ & \\
\hline \multicolumn{6}{|c|}{ Сем. Carangidae - Спаровые } \\
\hline 22. & $\begin{array}{l}\text { Diplodus annularis - } \\
\text { (L., 1758) - ласкирь }\end{array}$ & $\begin{array}{l}\text { ВУ, ВР, ЛЛ, } \\
\text { ПУ }\end{array}$ & КЧ & $\begin{array}{l}\text { Прибрежный вид, в условиях } \\
\text { наших визуальных и } \\
\text { видеонаблюдений - } \\
\text { немногочисленный, однако } \\
\text { достаточно обычный. Объект } \\
\text { любительского рыболовства } \\
\text { на прилегающей к } \\
\text { заповеднику акватории. В } \\
2016 \text { г. на мелководье } \\
\text { заповедной акватории } \\
\text { отмечено массовое } \\
\text { количество (2-3 тыс. особей } \\
\text { на } 1 \text { га) сеголетней молоди }\end{array}$ & Коч. \\
\hline 23. & $\begin{array}{l}\text { Diplodus puntazzo - } \\
\text { (Cetti, 1777) - } \\
\text { зубарик }\end{array}$ & BУ, BP & & $\begin{array}{l}\text { У берегов Карадага обычный } \\
\text { вид, встречающийся, тем не } \\
\text { менее, одиночно. Во время } \\
\text { наших визуальных и } \\
\text { видеонаблюдений - } \\
\text { немногочисленный. }\end{array}$ & Коч. \\
\hline \multicolumn{6}{|c|}{ Сем. Centracanthidae - Смаридовые } \\
\hline 24. & $\begin{array}{l}\text { Spicara flexuosa } \\
\text { Rafinesque, } 1810 \text { - } \\
\text { спикара, смарида }\end{array}$ & ЛЛ & КЧ & $\begin{array}{l}\text { Прибрежный пелагический } \\
\text { вид, нерегулярный объект } \\
\text { любительского лова у границ } \\
\text { заповедной акватории. }\end{array}$ & Миг. \\
\hline \multicolumn{6}{|c|}{ Сем. Sciaenidae - Горбылёвые } \\
\hline 25. & $\begin{array}{l}\text { Sciaena umbra L., } \\
1758 \text { - горбыль } \\
\text { темный }\end{array}$ & ВУ, ВР, ЛЛ & Берн & $\begin{array}{l}\text { Обитатель прибрежной зоны, } \\
\text { встречается среди подводных } \\
\text { камней. По данным А.Н. } \\
\text { Смирнова (1959) подход } \\
\text { горбыля в прибрежные воды } \\
\text { у Карарадага имеет место с } \\
\text { апреля по ноябрь (нерестится } \\
\text { в июне-августе, нерест } \\
\text { порционный, икра } \\
\text { пелагическая). В условиях } \\
\text { наших визуальных учётов и } \\
\text { видеонаблюдений } \\
\text { представлен } \\
\text { немногочисленными } \\
\text { взрослыми особями в } \\
\text { акватории у Камня Кузьмича } \\
\text { и сеголетней молодью, } \\
\text { обнаруженной в } 2015 \text { г. на } \\
\text { мелководье западнее причала } \\
\text { Биостанции. }\end{array}$ & Коч. \\
\hline \multicolumn{6}{|c|}{ Сем. Mullidae - Султанковые } \\
\hline 26. & $\begin{array}{l}\text { Mullus barbatus L., } \\
1758 \text { - султанка }\end{array}$ & $\begin{array}{l}\text { ВУ, ВР, ЛЛ, } \\
\text { ПУ }\end{array}$ & КЧ & $\begin{array}{l}\text { Прибрежный вид, обычный, } \\
\text { в период миграций - } \\
\text { массовый, в условиях наших }\end{array}$ & Миг. \\
\hline
\end{tabular}




\begin{tabular}{|c|c|c|c|c|c|}
\hline № & Виды & $\begin{array}{c}\text { Способ } \\
\text { обнаружения }\end{array}$ & $\begin{array}{c}\text { Природоохранный } \\
\text { статус }\end{array}$ & Информация & $\begin{array}{c}\text { Экологические } \\
\text { особенности }\end{array}$ \\
\hline & & & & $\begin{array}{l}\text { визуальных и } \\
\text { видеонаблюдений - } \\
\text { немногочисленный, однако } \\
\text { достаточно обычный. } \\
\text { Встречаются как молодь } \\
\text { (сеголетки, годовики), так и } \\
\text { взрослые особи. По данным } \\
\text { К.С. Ткачевой (1955) и Г.П. } \\
\text { Трифонова (1960), молодь у } \\
\text { берегов Карадага появляется } \\
\text { в конце июля - августе, что } \\
\text { совпадает и с нашими } \\
\text { наблюдениями. Объект } \\
\text { промысла и любительского } \\
\text { рыболовства на } \\
\text { прилегающей к заповеднику } \\
\text { акватории. }\end{array}$ & \\
\hline \multicolumn{6}{|c|}{ Сем. Pomacentridae - Помацентровые } \\
\hline 27. & $\begin{array}{l}\text { Chromis chromis L., } \\
1758 \text { - морская } \\
\text { ласточка }\end{array}$ & ВУ & & $\begin{array}{l}\text { Прибрежный вид, у берегов } \\
\text { Крыма попадается изредка, в } \\
\text { акватории заповедника не } \\
\text { обнаруживалась в течение } \\
\text { последних десятилетий. Во } \\
\text { время наших визуальных } \\
\text { исследований встретился в } \\
\text { западной части } \\
\text { Пуццолановой бухты около } \\
\text { вертикальной прибрежной } \\
\text { скалы на глубине } 3-5 \text { м } \\
\text { (приблизительно } 10 \text { осоей } \\
\text { сеголетней молоди) } \\
\text { (Смирнов, 2013) и у западной } \\
\text { вертикальной опоры скалы } \\
\text { «Золотые Ворота» (также } \\
\text { сеголетняя молодь } 2016 \text { г.). }\end{array}$ & Коч. \\
\hline \multicolumn{6}{|c|}{ Сем. Labridae -Губановые } \\
\hline 28. & $\begin{array}{l}\text { Crenilabrus cinereus } \\
\text { (Bonnaterre, 1788)- } \\
\text { рябчик }\end{array}$ & BP & & $\begin{array}{l}\text { Прибрежно-фитофильный } \\
\text { вид, для акватории } \\
\text { заповедника достаточно } \\
\text { редкий. }\end{array}$ & Коч. \\
\hline 29. & $\begin{array}{l}\text { Crenilabrus ocellatus } \\
\text { (Forsskal, 1775) - } \\
\text { губан глазчатый }\end{array}$ & ВУ, ВР & КЧ & $\begin{array}{l}\text { Прибрежный фоновый вид, } \\
\text { встречается среди заросших } \\
\text { водорослями камней. Во } \\
\text { время наших визуальных и } \\
\text { видеоучётов - от } \\
\text { немногочисленного до } \\
\text { массового. }\end{array}$ & Коч. \\
\hline 30. & $\begin{array}{l}\text { Crenilabrus roissali } \\
\text { (Risso, 1810) - } \\
\text { зеленушка } \\
\text { перепёлка }\end{array}$ & ВУ & & $\begin{array}{l}\text { Прибрежный фоновый вид, } \\
\text { встречается среди заросших } \\
\text { водорослями камней. Во } \\
\text { время наших визуальных и } \\
\text { видеоучётов - } \\
\text { немногочисленный. }\end{array}$ & Коч. \\
\hline
\end{tabular}




\begin{tabular}{|c|c|c|c|c|c|}
\hline № & Виды & $\begin{array}{c}\text { Способ } \\
\text { обнаружения }\end{array}$ & $\begin{array}{c}\text { Природоохранный } \\
\text { статус }\end{array}$ & Информация & $\begin{array}{c}\text { Экологические } \\
\text { особенности }\end{array}$ \\
\hline 31. & $\begin{array}{l}\text { Crenilabrus tinca } \\
\text { (L., 1758) - } \\
\text { зеленушка рулена }\end{array}$ & ВУ, ВР, ПУ & КЧ & $\begin{array}{l}\text { Массовый вид прибрежных } \\
\text { биотопов. Во время наших } \\
\text { наблюдений - самый } \\
\text { массовый, доминирующий } \\
\text { вид на всех участках. }\end{array}$ & Коч. \\
\hline \multicolumn{6}{|c|}{ Сем. Trachinidae - Морские дракончики } \\
\hline 32. & $\begin{array}{l}\text { Trahinus draco L., } \\
1758 \text { - дракончик } \\
\text { морской }\end{array}$ & лЛ & КЧ & $\begin{array}{l}\text { Донный вид, обитатель } \\
\text { песчаных грунтов. Часто } \\
\text { попадается на крючок во } \\
\text { время любительского лова } \\
\text { ставриды на прилегающей к } \\
\text { заповеднику акватории. }\end{array}$ & Осед. \\
\hline \multicolumn{6}{|c|}{ Сем. Trachinidae - Звездочётовые } \\
\hline 33. & $\begin{array}{l}\text { Uranoscopus scaber } \\
\text { L., } 1758 \text { - звездочет } \\
\text { (морская корова) }\end{array}$ & лЛ & КЧ & $\begin{array}{l}\text { Донный вид, тяготеющий к } \\
\text { песчаным грунтам. Редко } \\
\text { встречается в качестве } \\
\text { случайного прилова у } \\
\text { рыбаков-любителей на } \\
\text { прилегающей к заповеднику } \\
\text { акватории. }\end{array}$ & Осед. \\
\hline \multicolumn{6}{|c|}{ Сем. Tripterygiidae - Троепёрые } \\
\hline 34. & $\begin{array}{l}\text { Tripterygion } \\
\text { tripteronotus (Risso, } \\
\text { 1810) - троепёр }\end{array}$ & BУ & & $\begin{array}{l}\text { Донный вид. Обитает на } \\
\text { валунах и скалах в } \\
\text { разреженных зарослях } \\
\text { макрофитов. В районе } \\
\text { Карадага и Судака } \\
\text { характеризуется как } \\
\text { обычный вид (Шаганов, } \\
\text { 2009), однако во время } \\
\text { наших визуальных учётов } \\
\text { имели место две его находки } \\
\text { - в бухте Пуццолановой } \\
\text { (2013 г.) и на мелководье } \\
\text { западнее Камня Кузьмича } \\
\text { (2015 г.). }\end{array}$ & Осед. \\
\hline \multicolumn{5}{|c|}{ Сем. Blenniidae - Собачковые } & \\
\hline 35. & $\begin{array}{l}\text { Aidablennius sphynx } \\
\text { (Valenciennes, 1836) } \\
\text { - морская собачка- } \\
\text { сфинкс }\end{array}$ & ВУ & КЧ & $\begin{array}{l}\text { Донный вид. Населяет узкую } \\
\text { прибрежную зону ниже уреза } \\
\text { воды, обычно на гальке и } \\
\text { более крупных камнях, } \\
\text { свободных от } \\
\text { макроводорослей либо } \\
\text { покрытых разреженными } \\
\text { зарослями макрофитов. Во } \\
\text { время наших визуальных } \\
\text { учётов обычный вид, хотя и } \\
\text { немногочисленный. }\end{array}$ & Осед. \\
\hline 36. & $\begin{array}{l}\text { Salaria pavo (Risso, } \\
\text { 1810) - морская } \\
\text { собачка-павлин }\end{array}$ & ВУ & КЧ & $\begin{array}{l}\text { Донный прибрежный вид, } \\
\text { встречается на гальке и } \\
\text { валунах на глубине до } 2 \text { м. В } \\
\text { акватории заповедника } \\
\text { довольно редок. }\end{array}$ & Осед \\
\hline
\end{tabular}




\begin{tabular}{|c|c|c|c|c|c|}
\hline № & Виды & $\begin{array}{c}\text { Способ } \\
\text { обнаружения }\end{array}$ & $\begin{array}{c}\text { Природоохранный } \\
\text { статус }\end{array}$ & Информация & $\begin{array}{c}\text { Экологические } \\
\text { особенности }\end{array}$ \\
\hline 37. & $\begin{array}{l}\text { Parablennius } \\
\text { sanguinolentus } \\
\text { (Рallas, 1814) - } \\
\text { морская собачка } \\
\text { пятнистая (красная) }\end{array}$ & BУ, BP & & $\begin{array}{l}\text { Донный вид, характеризуется } \\
\text { как массовый, что совпадает } \\
\text { с результатами наших } \\
\text { визуальных учётов. В } \\
\text { акватории заповедника } \\
\text { является доминантным } \\
\text { видом прибрежного } \\
\text { ихтиокомплекса, встречается } \\
\text { повсеместно на каменистом } \\
\text { и галечниковом, заросшем } \\
\text { макроводорослями дне. }\end{array}$ & Осед. \\
\hline 38. & $\begin{array}{l}\text { Parablennius } \\
\text { zvonimiri } \\
\text { (Kolombatovic, } \\
\text { 1892) - морская } \\
\text { собачка Звонимира }\end{array}$ & BУ & & $\begin{array}{l}\text { Обитает преимущественно } \\
\text { на крупных подводных } \\
\text { камнях и скалах, встречается } \\
\text { единичными особями } \\
\text { преимущественно на } \\
\text { вертикальных поверхностях. } \\
\text { Нами во время визуальных } \\
\text { учётов встречены одиночные } \\
\text { особи на крупной гальке и } \\
\text { уступах восточной «стенки» } \\
\text { Львиной бухты, а также на } \\
\text { нагромождениях крупных } \\
\text { камней в небольшой бухте у } \\
\text { Кузьмичева Камня. }\end{array}$ & Осед. \\
\hline 39. & $\begin{array}{l}\text { Parablennius } \\
\text { tentacularis } \\
\text { (Brünnich, 1768) - } \\
\text { длиннощупальцевая } \\
\text { морская собачка }\end{array}$ & BУ & & $\begin{array}{l}\text { Встречается на валунно- } \\
\text { галечных грунтах и глыбах, } \\
\text { покрытых зарослями } \\
\text { макрофитов на глубинах } \\
\text { более } 1 \text { м. В акватории } \\
\text { Карадага встречается } \\
\text { единично или образует } \\
\text { небольшие группы (до } 10 \\
\text { особей на м²), но в целом } \\
\text { является обычным } \\
\text { немногочисленным видом. } \\
\text { Отмечена в акватории бухты } \\
\text { Карадагская (под пирсом } \\
\text { биостанции), на участке } \\
\text { между скалами «Кузмичев } \\
\text { Камень» и Левинсона- } \\
\text { Лессинга, в бухтах } \\
\text { Разбоничья, Пуццолановая, } \\
\text { Львиная. }\end{array}$ & Осед. \\
\hline 40 . & $\begin{array}{l}\text { Parablennius } \\
\text { incognitus (Bath, } \\
\text { 1968) - зеленая } \\
\text { морская собачка }\end{array}$ & BУ & & $\begin{array}{l}\text { В акватории Карадага очень } \\
\text { редкий вид, встречается } \\
\text { единичными особями. Был } \\
\text { отмечен в } 2002 \text { году на } \\
\text { валунно-галечном грунте в } \\
\text { районе скалы Левинсона- } \\
\text { Лессинга и в } 2017 \text { году на } \\
\text { вертикальной стенке скалы } \\
\text { Камни-Кузьмича в зарослях } \\
\text { Cladostephus spongiosus. }\end{array}$ & Осед. \\
\hline
\end{tabular}




\begin{tabular}{|c|c|c|c|c|c|}
\hline № & Виды & \begin{tabular}{|c|} 
Способ \\
обнаружения
\end{tabular} & $\begin{array}{c}\text { Природоохранный } \\
\text { статус }\end{array}$ & Информация & $\begin{array}{c}\text { Экологические } \\
\text { особенности }\end{array}$ \\
\hline 41. & $\begin{array}{l}\text { Coryphoblennius } \\
\text { galerita }(\mathrm{L} ., 1758)- \\
\text { хохлатая морская } \\
\text { собачка. }\end{array}$ & BУ & КЧ & $\begin{array}{l}\text { В акватории Карадага } \\
\text { обычный вид, встречается } \\
\text { единично в пределах всей } \\
\text { акватории. Держится в } \\
\text { зарослях зеленых } \\
\text { водорослей, в нишах на } \\
\text { крупных камнях на глубине } \\
\text { до } 2 \text { м. Нередко встречается } \\
\text { в углублениях на скалах и } \\
\text { камнях, заполненных водой и } \\
\text { находящиеся выше уровня } \\
\text { моря. }\end{array}$ & Осед. \\
\hline \multicolumn{6}{|c|}{ Сем. Gobiesocidae - Присосковые } \\
\hline 42. & $\begin{array}{l}\text { Lepadogaster } \\
\text { lepadogaster } \\
\text { (Bonnaterre, 1788)- } \\
\text { одноцветная рыба- } \\
\text { присоска }\end{array}$ & BУ & & $\begin{array}{l}\text { Обитает в зоне наката на } \\
\text { глубинах до 1,5 м, на } \\
\text { валунно-галечных грунтах, } \\
\text { лишенных зарослей } \\
\text { макрофитов. Держится на } \\
\text { нижней поверхности камней. } \\
\text { В акватории Карадага была } \\
\text { отмечена на участке между } \\
\text { скалами Кузмичев Камень и } \\
\text { Левинсона-Лессинга. }\end{array}$ & Осед \\
\hline 43. & $\begin{array}{l}\text { Lepadogaster } \\
\text { candollii Risso, } 1810 \\
\text { - присоска уточка }\end{array}$ & ВУ, ЛЛ & & \begin{tabular}{|l|} 
Обитает среди камней, \\
зарастающих \\
макроводорослями. Во время \\
наших визуальных учётов \\
этот вид отмечен в на \\
участке "Кузьмичев Камень" \\
в августе 2012 г.; в 2017 г. \\
поймано 2 особи в бухте \\
против дельфинария \\
Карадагской научной \\
станции.
\end{tabular} & Осед \\
\hline \multicolumn{6}{|c|}{ Сем. Gobiidae - Бычковые } \\
\hline 44. & $\begin{array}{l}\text { Gobius cobitis } \\
\text { Pallas, } 1814 \text { - } \\
\text { бычок-кругляш }\end{array}$ & ВУ, ЛЛ & КЧ & \begin{tabular}{|l|} 
Прибрежный донный вид, \\
обитает на галечных грунтах, \\
на валунах. В акватории \\
заповедника вид довольно \\
редкий. В 2002 г. обнаружен в \\
бухте Ливадия и у Кузьмичева \\
камня (Шаганов, 2004).
\end{tabular} & Осед. \\
\hline 45. & $\begin{array}{l}\text { Gobius paganellus } \\
\text { Linnaeus, } 1758 \text { - } \\
\text { бычок-паганель }\end{array}$ & & & $\begin{array}{l}\text { Прибрежный донный } \\
\text { фитофильный вид, обитает } \\
\text { на валунах. В акватории } \\
\text { заповедника вид довольно } \\
\text { редкий. Летом } 2017 \text { г. пойман } \\
\text { в бухте против дельфинария } \\
\text { Карадагской научной } \\
\text { станции. В } 2002 \text { г. обнаружен } \\
\text { в бухте против дельфинария } \\
\text { Карадагской научной } \\
\text { станции. (Шаганов, 2004). }\end{array}$ & Осед. \\
\hline
\end{tabular}




\begin{tabular}{|c|c|c|c|c|c|}
\hline № & Виды & $\begin{array}{c}\text { Способ } \\
\text { обнаружения }\end{array}$ & $\begin{array}{c}\text { Природоохранный } \\
\text { статус }\end{array}$ & Информация & $\begin{array}{c}\text { Экологические } \\
\text { особенности }\end{array}$ \\
\hline 46. & $\begin{array}{l}\text { Mesogobius } \\
\text { batrachocephalus } \\
\text { (Pallas, 1814)- } \\
\text { бычок-кнут }\end{array}$ & BУ & КЧ & $\begin{array}{l}\text { Прибрежный донный вид, } \\
\text { обитает на галечных грунтах } \\
\text { и среди камней, поросших } \\
\text { макроводорослями. Во время } \\
\text { наших визуальных учётов } \\
\text { единичные особи отмечались } \\
\text { единично в бухтах } \\
\text { Разбойничьей и Лягушачьей } \\
\text { (июль-август.2013), у скалы } \\
\text { «Золотые Ворота» (август } \\
\text { 2014) и на участке } \\
\text { «Кузьмичев Камень» (летние } \\
\text { месяцы 2015-17 гг.). }\end{array}$ & Осед. \\
\hline 47. & $\begin{array}{l}\text { Neogobius } \\
\text { eurycephalus } \\
\text { (Kessler, 1874)- } \\
\text { бычок-рыжик }\end{array}$ & BУ & & $\begin{array}{l}\text { Прибрежный донный вид, } \\
\text { обитает на галечных грунтах } \\
\text { на небольших (до 1 м) } \\
\text { глубинах. В акватории } \\
\text { заповедника вид довольно } \\
\text { обычный. }\end{array}$ & Осед. \\
\hline \multicolumn{6}{|c|}{ Cем. Scombridae - Скумбриевые } \\
\hline 48. & $\begin{array}{l}\text { Sarda sarda (Bloch, } \\
\text { 1793) - пеламида }\end{array}$ & ЛЛ & КЧ & $\begin{array}{l}\text { Пелагическая стайная рыба, } \\
\text { держится в основном в } \\
\text { верхних слоях воды. } \\
\text { Нерегулярно становится } \\
\text { объектом любительского } \\
\text { лова и промысла на } \\
\text { прилегающих к заповеднику } \\
\text { акваториях. }\end{array}$ & Миг. \\
\hline \multicolumn{6}{|c|}{ Сем. Soleidae - Солевые } \\
\hline 49. & $\begin{array}{l}\text { Solea nasuta (Pallas, } \\
\text { 1814) - морской } \\
\text { язык }\end{array}$ & ПУ & КЧ & $\begin{array}{l}\text { Прибрежный донный вид, } \\
\text { обитающий на песчаных } \\
\text { грунтах. Является объектом } \\
\text { промысла на прилегающей к } \\
\text { заповеднику акватории. }\end{array}$ & Осед. \\
\hline
\end{tabular}

Таблица 2.

Виды рыб, встреченные в акватории заповедника с 1993 по 2011 г. (кроме поименованных в таблице 1)

\begin{tabular}{|c|c|c|c|c|}
\hline № & Виды & $\begin{array}{c}\text { Последнее } \\
\text { обнаружение }\end{array}$ & Информация & $\begin{array}{c}\text { Экологические } \\
\text { особенности }\end{array}$ \\
\hline \multicolumn{5}{|c|}{ Сем. Clupeidae - Сельдевые } \\
\hline 1. & $\begin{array}{l}\text { Sardina pilchardus } \\
\text { (Walbaum, 1792) - } \\
\text { сардина }\end{array}$ & $\begin{array}{l}1997 \text { (Багнюкова, } \\
\text { 1998) }\end{array}$ & $\begin{array}{l}\text { Неоднократно ловилась ставным } \\
\text { неводом в п. Коктебель. }\end{array}$ & Коч. \\
\hline \multicolumn{5}{|c|}{ Сем. Syngnathidae - Игловые } \\
\hline 2. & $\begin{array}{l}\text { Syngnathus abaster Risso, } \\
1827 \text { - черноморская } \\
\text { пухлощекая игла-рыба }\end{array}$ & $\begin{array}{l}\text { июнь-июль 2002 } \\
\text { (Шаганов, 2004) }\end{array}$ & $\begin{array}{l}\text { Прибрежный фитофильный вид, обитает } \\
\text { в зарослях макрофитов, встречается и в } \\
\text { толще воды. В акватории заповедника } \\
\text { достаточно редок. }\end{array}$ & Коч. \\
\hline
\end{tabular}


Таблица 3.

Виды рыб, не встречавшиеся в акватории Карадагского природного заповедника более 25 лет

\begin{tabular}{|c|c|c|c|c|}
\hline & Виды & $\begin{array}{c}\text { Дата/год } \\
\text { последнего } \\
\text { обнаружения }\end{array}$ & Информация & $\begin{array}{c}\text { Источник } \\
\text { информации }\end{array}$ \\
\hline \multicolumn{5}{|c|}{ Сем. Acipenseridae - Осетровые } \\
\hline 1. & $\begin{array}{l}\text { Acipenser gueldenstaedtii } \\
\text { Brandt et Ratzeburg, } 1833 \text { - } \\
\text { русский осётр }\end{array}$ & 20.05 .1939 & $\begin{array}{l}\text { Очень редко попадали в орудия } \\
\text { лова молодые осетры }\end{array}$ & $\begin{array}{l}\text { Виноградов, } \\
\text { 1949* }\end{array}$ \\
\hline 2. & $\begin{array}{l}\text { Acipenser nudiventris } \\
\text { Lovetsky, } 1828 \text { - шип }\end{array}$ & 29.08 .1940 & $\begin{array}{l}\text { Молодой шип пойман дифоном } \\
\text { на глубине 3-4 м }\end{array}$ & $\begin{array}{l}\text { Виноградов, } \\
1949 *\end{array}$ \\
\hline 3. & $\begin{array}{l}\text { Acipenser stellatus Pallas, } 1771 \\
\text { - севрюга }\end{array}$ & 1959 & $\begin{array}{l}\text { Молодые севрюжата длиной } 32- \\
44 \text { см попадались в орудия лова }\end{array}$ & Смирнов, $1959 *$ \\
\hline 4. & Huso huso (L., 1758) - белуга & $1957 ?$ & $\begin{array}{l}\text { «Вблизи Судака рыболовецкий } \\
\text { колхоз в небольших количествах } \\
\text { промышляет белугу...» }\end{array}$ & Смирнов, 1959* \\
\hline \multicolumn{5}{|c|}{ Сем. Anguillidae - Угревые } \\
\hline 5. & $\begin{array}{l}\text { Anguilla anguilla (L., 1758) - } \\
\text { речной угорь }\end{array}$ & 03.12 .1986 & $\begin{array}{l}\text { Данные журнала исследований } \\
\text { выборок из уловов в бухте } \\
\text { Карадагской за 1983-1988 гг. }\end{array}$ & $\begin{array}{l}\text { Салехова, } \\
\text { Костенко, 1989* }\end{array}$ \\
\hline \multicolumn{5}{|c|}{ Сем. Clupeidae - Сельдевые } \\
\hline 6. & $\begin{array}{l}\text { Alosa caspia (Eichwald, 1838) } \\
\text { - каспийско-черноморский } \\
\text { пузанок }\end{array}$ & 1989 & $\begin{array}{l}\text { Редко, вся акватория заповедника, } \\
\text { очень редко }\end{array}$ & $\begin{array}{l}\text { Салехова, } \\
\text { Костенко, 1989* }\end{array}$ \\
\hline 7. & $\begin{array}{l}\text { Alosa fallax (Lacepede, 1803) - } \\
\text { средиземноморская финта }\end{array}$ & & $\begin{array}{l}\text { Достоверных данных о } \\
\text { нахождении вида у Карадага нет. } \\
\text { Упоминается о поимке финты в } \\
1924 \text { г. в Керченском проливе }\end{array}$ & $\begin{array}{l}\text { Виноградов, } \\
1949 *\end{array}$ \\
\hline 8. & $\begin{array}{l}\text { Clupeonella cultriventris } \\
\text { (Nordmann, 1840) - тюлька }\end{array}$ & 1957 & $\begin{array}{l}\text { «Чаще всего встречается в } \\
\text { январе-марте после сильных с-з } \\
\text { ветров, которые выгоняют её из } \\
\text { Азовского моря в Чёрное» }\end{array}$ & Смирнов, 1959* \\
\hline 9. & $\begin{array}{l}\text { Sardinella aurita Valenciennes, } \\
1847 \text { - сардинелла }\end{array}$ & 29.06 .1988 & $\begin{array}{l}\text { Данные журнала исследований } \\
\text { выборок из уловов в бухте } \\
\text { Карадагской за 1983-1988 гг. }\end{array}$ & $\begin{array}{l}\text { Салехова, } \\
\text { Костенко, 1989* }\end{array}$ \\
\hline 10. & $\begin{array}{l}\text { Sprattus sprattus (L., 1758) - } \\
\text { шпрот (килька) }\end{array}$ & 21.06.1988 & $\begin{array}{l}\text { Данные журнала исследований } \\
\text { выборок из уловов в бухте } \\
\text { Карадагской за 1983-1988 гг. }\end{array}$ & $\begin{array}{l}\text { Салехова, } \\
\text { Костенко, 1989* }\end{array}$ \\
\hline \multicolumn{5}{|c|}{ Сем. Salmonidae - Лососевые } \\
\hline 11. & Salmo trutta L., 1758 - лосось & 1955 & Пойман волокушей 1 экз. & Смирнов, 1959* \\
\hline \multicolumn{5}{|c|}{ Cем. Lophiidae - Удильщиковые } \\
\hline 12. & $\begin{array}{l}\text { Lophius piscatorius L., } 1758 \text { - } \\
\text { европейский удильщик } \\
\text { (морской черт) }\end{array}$ & 1951 & $\begin{array}{l}\text { «В мае } 1951 \text { г. один экземпляр } \\
\text { был пойман в камбальные сети» }\end{array}$ & Смирнов, 1959* \\
\hline \multicolumn{5}{|c|}{ Сем. Cyprinidae - Карповые } \\
\hline 13. & Abramis brama L., 1758 - лещ & 03.04 .1940 & $\begin{array}{l}\text { «Выброшенный волнами на берег } \\
\text { экземпляр леща длиной до } \\
450 \text { мм...» }\end{array}$ & $\begin{array}{l}\text { Виноградов, } \\
\text { 1949* }\end{array}$ \\
\hline
\end{tabular}




\begin{tabular}{|c|c|c|c|c|}
\hline & Виды & $\begin{array}{c}\text { Дата/год } \\
\text { последнего } \\
\text { обнаружения }\end{array}$ & Информация & $\begin{array}{c}\text { Источник } \\
\text { информации }\end{array}$ \\
\hline 14. & $\begin{array}{l}\text { Carassius gibelio (Bloch, 1782) } \\
\text { - карась серебряный }\end{array}$ & 06.06 .1985 & $\begin{array}{l}\text { Данные журнала исследований } \\
\text { выборок из уловов в бухте } \\
\text { Карадагской за 1983-1988 гг. } \\
\text { Накануне прошел сильный } \\
\text { ливень }\end{array}$ & $\begin{array}{l}\text { Салехова, } \\
\text { Костенко, 1989* }\end{array}$ \\
\hline 15. & $\begin{array}{l}\text { Cyprinus carpio L., } 1758 \text { - } \\
\text { сазан }\end{array}$ & 11.06.1985 & $\begin{array}{l}\text { Единичная поимка в бухте } \\
\text { Карадагской. }\end{array}$ & $\begin{array}{l}\text { Костенко, } \\
\text { Шаганов, } 2004\end{array}$ \\
\hline 16. & $\begin{array}{l}\text { Rutilus rutilus (L., 1758) - } \\
\text { тарань }\end{array}$ & & $\begin{array}{l}\text { Оснований для внесения в списки } \\
\text { не выявлено }\end{array}$ & $\begin{array}{l}\text { Прокудина, } \\
\text { 1952*, Смирнов, } \\
\text { 1959* }\end{array}$ \\
\hline \multicolumn{5}{|c|}{ Сем. Mugilidae - Кефалевые } \\
\hline 17. & $\begin{array}{l}\text { Liza saliens (Risso, 1810)- } \\
\text { остронос }\end{array}$ & 1997 & $\begin{array}{l}\text { В планктоне обнаружена икра. Не } \\
\text { отмечено ни молоди, ни взросльхх } \\
\text { рыб. }\end{array}$ & $\begin{array}{l}\text { Багнюкова, } \\
1998 *\end{array}$ \\
\hline \multicolumn{5}{|c|}{ Сем. Atherinidae - Атериновые } \\
\hline 18. & $\begin{array}{l}\text { Atherina hepsetus L., } 1758 \text { - } \\
\text { атлантическая } \\
\text { (средиземноморская) атерина }\end{array}$ & 1957 & $\begin{array}{l}\text { Встречалась в промысловых } \\
\text { уловах }\end{array}$ & Смирнов, 1959* \\
\hline \multicolumn{5}{|c|}{ Сем. Zeidae - Солнечниковые } \\
\hline 19. & $\begin{array}{l}\text { Zeus faber L., } 1758 \text { - } \\
\text { обыкновенный солнечник }\end{array}$ & Май 1956 & Пойман 1 экз. & Смирнов, 1959* \\
\hline \multicolumn{5}{|c|}{ Сем. Syngnathidae - Игловые } \\
\hline 20. & $\begin{array}{l}\text { Nerophis ophidion (L., 1758) - } \\
\text { змеевидная игла-рыба }\end{array}$ & 1940 & $\begin{array}{l}\text { Встречалась в разных орудиях } \\
\text { лова }\end{array}$ & $\begin{array}{l}\text { Виноградов, } \\
1949 *\end{array}$ \\
\hline 21. & $\begin{array}{l}\text { Syngnathus acus L., } 1758 \text { - } \\
\text { обыкновенная игла-рыба }\end{array}$ & 1957 & $\begin{array}{l}\text { Встречалась в сетях с апреля по } \\
\text { ноябрь }\end{array}$ & Смирнов, 1959* \\
\hline 22. & $\begin{array}{l}\text { Syngnathus schmidti Popov, } \\
1927 \text { - черноморская } \\
\text { шиповатая игла-рыба }\end{array}$ & 1957 & $\begin{array}{l}\text { Встречалась в сетях с апреля по } \\
\text { ноябрь }\end{array}$ & Смирнов, 1959* \\
\hline 23. & $\begin{array}{l}\text { Syngnathus tenuirostris Rathke, } \\
1837 \text { - тонкорылая игла-рыба }\end{array}$ & 14.06 .1985 & $\begin{array}{l}\text { Данные журнала исследований } \\
\text { выборок из уловов в бухте } \\
\text { Карадагской за 1983-1988 гг. }\end{array}$ & $\begin{array}{l}\text { Салехова, } \\
\text { Костенко, 1989* }\end{array}$ \\
\hline 24. & $\begin{array}{l}\text { Syngnathus variegatus Pallas, } \\
1814 \text { - толсторылая игла- } \\
\text { рыба }\end{array}$ & 1957 & $\begin{array}{l}\text { Встречалась в сетях с апреля по } \\
\text { ноябрь }\end{array}$ & Смирнов, 1959* \\
\hline \multicolumn{5}{|c|}{ Сем. Moronidae - Лавраковые } \\
\hline 25. & $\begin{array}{l}\text { Dicentrarchus labrax (L., 1758) } \\
\text { - лаврак }\end{array}$ & & $\begin{array}{l}\text { «... возможна находка и у } \\
\text { Карадага» }\end{array}$ & $\begin{array}{l}\text { Виноградов, } \\
\text { 1949* }\end{array}$ \\
\hline 26. & $\begin{array}{l}\text { Morone saxatilis (Walbaum, } \\
\text { 1792) - полосатый окунь }\end{array}$ & 1995 & Пойман 1 экземпляр. & $\begin{array}{l}\text { Багнюкова, } \\
\text { 1998* }\end{array}$ \\
\hline \multicolumn{5}{|c|}{ Сем. Serranidae - Серрановые } \\
\hline 27. & $\begin{array}{l}\text { Serranus scriba (L., 1758) - } \\
\text { каменный окунь-зебра }\end{array}$ & 1957 & $\begin{array}{l}\text { Встречался в уловах с мая по } \\
\text { ноябрь. }\end{array}$ & Смирнов, 1959* \\
\hline \multicolumn{5}{|c|}{ Сем. Percidae - Окуневые } \\
\hline 28. & Stizostedion (Sander) & Не позднее 1947 & По-видимому, попадают в Черное & Виноградов, \\
\hline
\end{tabular}




\begin{tabular}{|c|c|c|c|c|}
\hline & Виды & $\begin{array}{c}\text { Дата/год } \\
\text { последнего } \\
\text { обнаружения }\end{array}$ & Информация & $\begin{array}{c}\text { Источник } \\
\text { информации }\end{array}$ \\
\hline & lucioperca (L.) - судак & & море из Азовского & $1949 *$ \\
\hline \multicolumn{5}{|c|}{ Сем. Sparidae - Спаровые } \\
\hline 29. & Boops boops (L., 1758) - бопс & 23.06.1988 & $\begin{array}{l}\text { Данные журнала исследований } \\
\text { выборок из уловов в бухте } \\
\text { Карадагской за 1983-1988 гг. }\end{array}$ & $\begin{array}{l}\text { Салехова, } \\
\text { Костенко, 1989* }\end{array}$ \\
\hline \multicolumn{5}{|c|}{ Сем. Centracanthidae - Смаридовые } \\
\hline 30. & $\begin{array}{l}\text { Spicara maena }(\mathrm{L} ., 1758)- \\
\text { мэнола, средиземноморская } \\
\text { смарида }\end{array}$ & 02.06.1981 & Единичная встреча & $\begin{array}{l}\text { Салехова, } \\
\text { Костенко, 1989* }\end{array}$ \\
\hline \multicolumn{5}{|c|}{ Сем. Sciaenidae - Горбылевые } \\
\hline 31. & $\begin{array}{l}\text { Umbrina cirrosa (L., 1758) - } \\
\text { светлый горбыль }\end{array}$ & $\begin{array}{c}\text { Не позднее } 1957 \\
\text { г. }\end{array}$ & Редко попадал в рыбацкие сети & Смирнов, 1959* \\
\hline \multicolumn{5}{|c|}{ Сем. Labridae - Губановые } \\
\hline 32. & $\begin{array}{l}\text { Ctenolabrus rupestris (L., } \\
\text { 1758) - красный губан } \\
\text { (лапина) }\end{array}$ & 12.07.1984 & $\begin{array}{l}\text { Данные журнала исследований } \\
\text { выборок из уловов в бухте } \\
\text { Карадагской за 1983-1988 гг. }\end{array}$ & $\begin{array}{l}\text { Салехова, } \\
\text { Костенко, 1989* }\end{array}$ \\
\hline 33. & $\begin{array}{l}\text { Symphodus scina (Forsskal, } \\
\text { 1775) - носатый губан }\end{array}$ & 04.07 .1984 & $\begin{array}{l}\text { Данные журнала исследований } \\
\text { выборок из уловов в бухте } \\
\text { Карадагской за 1983-1988 гг. }\end{array}$ & $\begin{array}{l}\text { Салехова, } \\
\text { Костенко, 1989* }\end{array}$ \\
\hline \multicolumn{5}{|c|}{ Сем. Ammodytidae - Песчанковые } \\
\hline 34. & $\begin{array}{l}\text { Gymnammodytes cicerelus } \\
\text { (Rafinesque, 1810) - голая } \\
\text { песчанка }\end{array}$ & 1945 & $\begin{array}{l}\text { Отмечается как довольно } \\
\text { обычный вид }\end{array}$ & $\begin{array}{l}\text { Виноградов, } \\
\text { 1949* }\end{array}$ \\
\hline \multicolumn{5}{|c|}{ Сем. Gobiesocidae - Присосковые } \\
\hline 35 . & $\begin{array}{l}\text { Diplecogaster bimaculata } \\
\text { (Bonnaterre, 1788) - } \\
\text { пятнистая присоска }\end{array}$ & 1989 & $\begin{array}{l}\text { Отмечалась в июне-июле на } \\
\text { каменистых грунтах, очень редкая }\end{array}$ & $\begin{array}{l}\text { Салехова, } \\
\text { Костенко, 1989* }\end{array}$ \\
\hline \multicolumn{5}{|c|}{ Сем. Callionymidae - Лировые } \\
\hline 36. & $\begin{array}{l}\text { Callionymus pusillus } \\
\text { Delaroche, } 1809 \text { - морская } \\
\text { мышь (бурая пескарка) }\end{array}$ & 24.07 .1987 & $\begin{array}{l}\text { Данные журнала исследований } \\
\text { выборок из уловов в бухте } \\
\text { Карадагской за 1983-1988 гг. }\end{array}$ & $\begin{array}{l}\text { Салехова, } \\
\text { Костенко, 1989* }\end{array}$ \\
\hline 37. & $\begin{array}{l}\text { Callionymus risso Lesueur, } \\
1814 \text { - малая морская мышь }\end{array}$ & & $\begin{array}{l}\text { Этот вид указан для Керченского } \\
\text { пролива }\end{array}$ & $\begin{array}{l}\text { Виноградов, } \\
\text { 1949* }\end{array}$ \\
\hline 38. & $\begin{array}{l}\text { Callionymus lyra L., } 1758 \text { - } \\
\text { морская мышь лира }\end{array}$ & 27.08.1985 & $\begin{array}{l}\text { Данные журнала исследований } \\
\text { выборок из уловов в бухте } \\
\text { Карадагской за 1983-1988 гг. }\end{array}$ & $\begin{array}{l}\text { Салехова, } \\
\text { Костенко, 1989* }\end{array}$ \\
\hline \multicolumn{5}{|c|}{ Сем. Gobiidae - Бычковые } \\
\hline 39. & $\begin{array}{l}\text { Aphia minuta (Risso, 1810) - } \\
\text { бланкет }\end{array}$ & $\begin{array}{l}1957, \\
1989 ?\end{array}$ & $\begin{array}{l}\text { Встречался в уловах волокушей. } \\
\text { С } 1989 \text { г. в планктоне встречались } \\
\text { личинки, не определённые до } \\
\text { вида. }\end{array}$ & $\begin{array}{l}\text { Смирнов, } \\
\text { 1959*; } \\
\text { Багнюкова, } \\
1998 *\end{array}$ \\
\hline 40 . & $\begin{array}{l}\text { Benthophilus stellatus } \\
\text { (Sauvage, 1874) - звездчатая } \\
\text { пуголовка }\end{array}$ & Не позднее 1958 & $\begin{array}{l}\text { Значится в общем списке, однако, } \\
\text { никаких данных не приводится }\end{array}$ & Смирнов, 1959* \\
\hline 41. & Gobius bucchichi Steindachner, & Не позднее & & Салехова, \\
\hline
\end{tabular}




\begin{tabular}{|c|c|c|c|c|}
\hline & Виды & $\begin{array}{c}\text { Дата/год } \\
\text { последнего } \\
\text { обнаружения }\end{array}$ & Информация & $\begin{array}{c}\text { Источник } \\
\text { информации }\end{array}$ \\
\hline & 1870 - бурый бычок & 1988 г. & & Костенко, 1989* \\
\hline 42. & $\begin{array}{l}\text { Gobius niger L., } 1758 \text { - } \\
\text { черный бычок }\end{array}$ & 28.04.1988 & $\begin{array}{l}\text { Данные журнала исследований } \\
\text { выборок из уловов в бухте } \\
\text { Карадагской за 1983-1988 гг. }\end{array}$ & $\begin{array}{l}\text { Салехова, } \\
\text { Костенко, 1989* }\end{array}$ \\
\hline 43. & $\begin{array}{l}\text { Gobius ophicephalus Pallas, } \\
1814 \text { - травяной бычок }\end{array}$ & 1957 & $\begin{array}{l}\text { Встречался в небольшом } \\
\text { количестве }\end{array}$ & Смирнов, 1959* \\
\hline 44. & $\begin{array}{l}\text { Neogobius fluviatilis (Pallas, } \\
\text { 1814) - бычок-песочник }\end{array}$ & & $\begin{array}{l}\text { Нет данных о нахождении вида на } \\
\text { Карадаге. Отмечался в районе } \\
\text { Керчи и на реке Карасу близь } \\
\text { Белогорска }\end{array}$ & $\begin{array}{l}\text { Виноградов, } \\
\text { 1949* }\end{array}$ \\
\hline 45. & $\begin{array}{l}\text { Neogobius gymnotrachelus } \\
\text { (Kessler, 1857) - бычок-гонец }\end{array}$ & 21.06 .1985 & $\begin{array}{l}\text { Данные журнала исследований } \\
\text { выборок из уловов в бухте } \\
\text { Карадагской за 1983-1988 гг. }\end{array}$ & $\begin{array}{l}\text { Салехова, } \\
\text { Костенко, 1989* }\end{array}$ \\
\hline 46. & $\begin{array}{l}\text { Neogobius kessleri (Gunther, } \\
\text { 1861) - бычок-головач }\end{array}$ & 06.07 .1983 & $\begin{array}{l}\text { Данные журнала исследований } \\
\text { выборок из уловов в бухте } \\
\text { Карадагской за 1983-1988 гг. }\end{array}$ & $\begin{array}{l}\text { Салехова, } \\
\text { Костенко, 1989* }\end{array}$ \\
\hline 47. & $\begin{array}{l}\text { Neogobius melanostomus } \\
\text { (Pallas, 1814) - бычок-кругляк }\end{array}$ & 18.05 .1988 & $\begin{array}{l}\text { Данные журнала исследований } \\
\text { выборок из уловов в бухте } \\
\text { Карадагской за 1983-1988 гг. }\end{array}$ & $\begin{array}{l}\text { Салехова, } \\
\text { Костенко, 1989* }\end{array}$ \\
\hline 48. & $\begin{array}{l}\text { Neogobius platyrostris (Pallas, } \\
\text { 1814) - бычок-губан }\end{array}$ & 10.08 .1984 & $\begin{array}{l}\text { Данные журнала исследований } \\
\text { выборок из уловов в бухте } \\
\text { Карадагской за 1983-1988 гг. }\end{array}$ & $\begin{array}{l}\text { Салехова, } \\
\text { Костенко, 1989* }\end{array}$ \\
\hline 49. & $\begin{array}{l}\text { Neogobius ratan (Pallas, 1814) } \\
\text { - бычок-ротан }\end{array}$ & 1957 & $\begin{array}{l}\text { Встречался в небольшом } \\
\text { количестве }\end{array}$ & Смирнов, 1959* \\
\hline 50. & $\begin{array}{l}\text { Neogobius syrman (Nordmann, } \\
\text { 1840) - бычок-ширман }\end{array}$ & 1957 & $\begin{array}{l}\text { Встречался в небольшом } \\
\text { количестве }\end{array}$ & Смирнов, 1959* \\
\hline 51. & $\begin{array}{l}\text { Pomatoschistus marmoratus } \\
\text { (Risso, 1810) - леопардовый } \\
\text { лысун }\end{array}$ & $\begin{array}{c}\text { Не позднее } \\
1948 \text { г. }\end{array}$ & $\begin{array}{l}\text { Встречался в небольшом } \\
\text { количестве }\end{array}$ & Смирнов, 1959* \\
\hline 52. & $\begin{array}{l}\text { Pomatoschistus minutus } \\
\text { (Pallas, 1770) - малый лысун }\end{array}$ & $1989 ?$ & $\begin{array}{l}\text { С } 1989 \text { г. в планктоне встречались } \\
\text { личинки, не определённые до } \\
\text { вида. }\end{array}$ & $\begin{array}{l}\text { Багнюкова, } \\
\text { 1998* }\end{array}$ \\
\hline 53. & $\begin{array}{l}\text { Proterorhinus marmoratus } \\
\text { (Pallas, 1814) - бычок-цуцик }\end{array}$ & 1957 & $\begin{array}{l}\text { Встречался в небольшом } \\
\text { количестве }\end{array}$ & Смирнов, 1959* \\
\hline \multicolumn{5}{|c|}{ Сем. Scombridae - Скумбриевые } \\
\hline 54. & $\begin{array}{l}\text { Scomber scombrus L., } 1758 \text { - } \\
\text { скумбрия }\end{array}$ & 1952 & $\begin{array}{l}\text { В небольшом количестве } \\
\text { попадалась с июня по ноябрь }\end{array}$ & Смирнов, 1959* \\
\hline 55. & $\begin{array}{l}\text { Thunnus thunnus (L., 1758) - } \\
\text { обыкновенный (синий) тунец }\end{array}$ & 1957 & $\begin{array}{l}\text { Встречена икра в планктоне } \\
\text { Л.С.Овен }\end{array}$ & $\begin{array}{l}\text { Костенко, } \\
\text { Шаганов, } 2004\end{array}$ \\
\hline \multicolumn{5}{|c|}{ Сем. Xiphiidae - Меч-рыбы } \\
\hline 56. & $\begin{array}{l}\text { Xiphias gladius L., } 1758 \text { - меч- } \\
\text { рыба }\end{array}$ & 1991 & $\begin{array}{l}\text { Т.В. Багнюковой обнаружена } \\
\text { икринка в Лисьей бухте }\end{array}$ & $\begin{array}{l}\text { Багнюкова, } \\
1998 *\end{array}$ \\
\hline \multicolumn{5}{|c|}{ Cем. Bothidae - Ботусовые } \\
\hline 57. & $\begin{array}{l}\text { Arnoglossus kessleri Schmidt, } \\
1915 \text { - арноглосс Кесслера }\end{array}$ & 25.06.1984 & $\begin{array}{l}\text { Данные журнала исследований } \\
\text { выборок из уловов в бухте } \\
\text { Карадагской за 1983-1988 гг. }\end{array}$ & $\begin{array}{l}\text { Салехова, } \\
\text { Костенко, 1989* }\end{array}$ \\
\hline
\end{tabular}




\begin{tabular}{|c|c|c|c|c|}
\hline & Виды & $\begin{array}{c}\text { Дата/год } \\
\text { последнего } \\
\text { обнаружения }\end{array}$ & Информация & $\begin{array}{c}\text { Источник } \\
\text { информации }\end{array}$ \\
\hline \multicolumn{5}{|c|}{ Сем. Scophthalmidae - Ромбовые } \\
\hline 58. & $\begin{array}{l}\text { Scophthalmus maeoticus } \\
\text { (Pallas, 1814) - черноморский } \\
\text { калкан }\end{array}$ & 18.05 .1988 & $\begin{array}{l}\text { Встречается единично, редко, на } \\
\text { песчаных грунтах в мае--октябре }\end{array}$ & $\begin{array}{l}\text { Салехова, } \\
\text { Костенко, 1989* }\end{array}$ \\
\hline 59. & $\begin{array}{l}\text { Scophthalmus rhombus (L., } \\
\text { 1758) - гладкий ромб }\end{array}$ & Июль 1946 & $\begin{array}{l}2 \text { особи в уловах Карадагской } \\
\text { биостанции }\end{array}$ & \\
\hline \multicolumn{5}{|c|}{ Сем. Pleuronectidae - Камбаловые } \\
\hline 60. & $\begin{array}{l}\text { Platichthys flesus (L., 1758) - } \\
\text { речная камбала (глосса) }\end{array}$ & 18.05.1988 & $\begin{array}{l}\text { Данные журнала исследований } \\
\text { выборок из уловов в бухте } \\
\text { Карадагской за 1983-1988 гг. }\end{array}$ & $\begin{array}{l}\text { Салехова, } \\
\text { Костенко, 1989* }\end{array}$ \\
\hline
\end{tabular}

*Более поздние упоминания цитируют данный источник

Таким образом, общее количество видов ихтиокомплекса акватории Карадагского природного заповедника насчитывает 51 (табл. 1, 2). Среди них оседлых 20 , кочевников - 17 , т.е. 36 видов (73\%) достаточно устойчиво приурочены к биотопам заповедной акватории. Мигрирующих видов среди присутствующих в акватории заповедника - 14 (27\%).

Из видов, присутствие которых в акватории заповедника можно считать подтверждённым, в Красную книгу Республики Крым (2015) включено 2 вида, в Красный список Международного союза охраны природы (МСOП, IUCN) - 3 (учитывались только угрожаемые категории - в нашем случае «Endangered» и «Vulnerable») (European Red List of Marine Fishes, 2015), в Красную книгу Чёрного моря (Black Sea Red Data Book, 1999) - 18; в охранные списки Бернской конвенции включены 3 вида. 8 видов из поименованных в табл. 1 и 2 в акватории заповедника являются редкими: катран, морская лисица, трёхиглая колюшка, морской конёк, морская ласточка, троепёр, присоска-уточка, одноцветная рыба-присоска.

\section{Выводы}

1. В период 2012-2017 гг. доступными для исследования методами (визуальный учёт и видеоучёт в акватории Карадагского заповедника, данные промстатистики и информация от рыбаков-любителей, осуществляющих лов на примыкающих к заповеднику акваториях) выявлено 49 видов рыб. Анализ литературных данных об изучении ихтиокомплекса акватории заповедника за предшествующие 25 лет показал, что ещё 2 вида также могут быть отнесены к ихтиокомплексу акватории заповедника. Таким образом, общее количество видов ихтиокомплекса акватории Карадагского природного заповедника насчитывает 51.

2. Из упомянутых видов, составляющих ихтиокомплекс акватории Карадагского природного заповедника (51), в Красную книгу Республики Крым включено 2 вида, в Красный список Мирового союза охраны природы (MCOП, IUCN) - 3, в Красную книгу Чёрного моря (Black Sea Red Data Book, 1999) - 18, в охранные списки Бернской конвенции -3 вида. 8 видов, обитающих в акватории заповедника, являются редкими. 


\section{Благодарности}

Авторы глубоко признательны Н.С. Костенко за предоставленные материалы обработки уловов за 1983-1988 гг. и В.А. Дроздову за предоставленные данные промысловых уловов в западной части Коктебельского залива.

\section{Список литературы}

1. Багнюкова T.B. Ихтиофауна // Карадагский природный заповедник. Летопись природы, 1997. - Карадаг, 1998. - С. 57-65.

2. Васильева Е.Д. Рыбы Черного моря. Определитель морских, солоноватоводных, эвригалинных и проходных видов с цветными иллюстрациями, собранными С.В. Богородским. - М.: Изд-во ВНИРО, 2007. - 238 с.

3. Виноградов К.А. Материалы по ихтиофауне района Карадагской биологической станции (Чёрное море) // Труды Карадагской биологической станции. - 1930. Вып. 3. - С. 137-143.

4. Виноградов К.A. Список рыб Чёрного моря, встречающихся в районе Карадагской биологической станции, с замечаниями об их биологии и экологии // Труды Карадагской биологической станции. - 1949. - Вып. 7. - С. 76-106.

5. Виноградов К.О. Список риб Чорного моря, що зустрічаються в районі Карадагської біологічної станції // Доповіді Академії наук УРСР. Відділ біол. Наук. - 1947. - № 5. - C. 57-61.

6. Гетьман Т.П. Визуальные подводные наблюдения при оценке качественноколичественных показателей ихтиоцена // Экология моря. - 2007. - Вып. 74. - С. 13-17.

7. Костенко Н.С., Шаганов В.В. Рыбы // Карадаг. Гидробиологические исследования. Сборник научных трудов, посвящённый 90-летию Карадагской научной станции им. Т.И. Вяземского и 25-летию Карадагского природного заповедника НАН Украины. Книга 2-я. - Симферополь: СОНАТ, 2004. - С. 440-453.

8. Красная книга Республики Крым. Животные. - Симферополь: ООО ИТ «АРИАЛ», 2015. - $436 \mathrm{c}$.

9. Мальцев В.И., Алексеев А.Н. Оценка состояния прибрежного ихтиокомплекса заповедной акватории при помощи подводного автономного видеорегистрирующего устройства // Труды Карадагской научной станции им. Т.И. Вяземского - природного заповедника РАН. - 2016. - Вып. 2. - С. 44-51.

10. Мальцев В.И., Иванчикова Ю.Ф. Прибрежный ихтиокомплекс акватории Карадагского природного заповедника (Чёрное море, Крым) // 100 лет Карадагской научной станции им. Т.И. Вяземского: сборник научных трудов. - Симферополь: Н. Оріанда, 2015. - С. 584-589.

11. Овен Л.С. О подходах молоди луфаря к берегам Черного моря в районе Карадага (1947-1954) // Труды Карадагской биологической станции. - 1957. - Вып. 14. C. $155-157$.

12. Прокудина Л.А. Каталог фауны и флоры Чёрного моря района Карадагской биологической станции // Труды Карадагской биологической станции. - 1952. Вып. 12. - С. 116-127.

13. Салехова Л.П., Костенко Н.С. Рыбы // Флора и фауна заповедников СССР. Фауна Карадагского заповедника (паразитофауна рыб; рыбы; земноводные и пресмыкающиеся; птицы; млекопитающие) - М.: Производственно-издательский комбинат ВИНИТИ, 1989. - С. 21-33. 
14. Салехова Л.П., Костенко Н.С., Богачик Т.А., Минибаева О.Н. Состав ихтиофауны в районе Карадагского заповедника (Чёрное море) // Вопросы ихтиологии. - 1987. Т. 27, Вып. 6. - С. 898-905.

15. Смирнов А.Н. Материалы по биологии рыб Черного моря в районе Карадага // Труды Карадагской биологической станции. - 1959. - Вып. 15. - С. 31-109.

16. Смирнов Д.Ю. Обнаружение мальков морской ласточки Chromis chromis (Perciformes: Pomacentridae) у побережья Карадагского природного заповедника // Морський екологічний журнал. - 2013. - Т. ХІІ. - Вып. 1. - С. 26.

17. Ткачёва K.C. К биологии мальков черноморской султанки (Mullus barbatus ponticus Ess.) // Труды Карадагской биологической станции. - 1955. - Вып. 13. - С. 59-69.

18. Трифонов Г.П. Питание молоди некоторых видов рыб в прибрежной зоне Черного моря у Карадага // Труды Карадагской биологической станции. - 1960. - Вып. 16. C. $160-168$.

19. Шаганов B.B. Видовой состав и экололгическая структура ихтиоцена твёрдых грунтов прибрежной зоны Карадагского природного заповедника НАН Украины // Карадагский природный заповедник. Летопись природы. - 2002. - Т. XIX. Симфереполь: СОНАТ, 2004. - С. 125-128

20. Шаганов B.B. Предварительный обзор ихтиофауны черноморского побережья Юговосточного Крыма // Карадаг - 2009: Сборник научных трудов, посвящённый 95летию Карадагской научной станции и 30-летию Карадагского природного заповедника Национальной академии наук Украины. - Севастополь: ЭКОСИГидрофизика, 2009. - С. 262-273.

21. European Red List of Marine Fishes. - Luxembourg: Publications Office of the European Union, $2015-81 \mathrm{p}$.

22. Black Sea Red Data Book / Ed. by H.J. Dumont. - New York: Unit. Nat. Office for Project Serv., 1999. - 413 p.

\author{
CURRENT STATE OF ICHTHYO-COMPLEX \\ OF THE KARADAG NATURE RESERVE \\ ${ }^{1}$ Maltsev V.I., ${ }^{2}$ Shaganov V.V., ${ }^{1}$ Vasilets V.E. \\ ${ }^{I}$ T.I.Vyazemsky Karadag Scientific Station - Nature Reserve of the RAS, \\ Feodosia, Kurortnoe, Russian Federation,e-mail: maltsev1356@gmail.com \\ ${ }^{2}$ Kerch State Maritime Tecnological University, \\ Kerch, Russian Federation, e-mail:vvshaganov@yandex.ru
}

During 2012-2017, 49 fish species were recognized at the aquatory of the Karadag Nature Reserve with methods of visual registration and video registration, as well as on the basis of data of catch statistics and information from the amateur fishermen who are carrying out fishing on the adjoining aquatory. The analysis of literary data on studying of ichthyo-complex of the aquatory of the reserve for 25 years back showed that 2 more species can be also added to the ichthyo-complex of the water area of the reserve. Thus, the total number of species of mentioned ichthyo-complex is 51 . The other 60 species which were earlier included into the lists of species of the aquatory of the reserve are not met here over 25 years, or is combined with other species as a result of revision of their systematics. Amomg 51 species mentioned above 2 species are included into the Red Data Book of Crimea, 3 into the IUCN Red List, 3 - into the protection lists of the Bern convention. 18 species are included into the Black Sea Red Data Book. 8 species dwelling at the aquatory of the reserve are rare.

Key words: Karadag Nature Reserve, aquatory of the reserve, fish species, visual registration, videoregistration, catch statitics, recreational fishing data.

Поступила в редакиию 24.06.2017 г. 